\title{
Capital Flows, Turbulences, and Distribution: The Case of Turkey
}

\author{
Özlem Onaran*
}

This paper presents the mechanism of the boom-bust cycles in the context of domestic and international financial liberalisation in the developing countries, and the effects of crises and exchange rate volatility on functional income distribution. It is based on the case of Turkey, which has experienced two severe crises in 1994 and 2001 after the liberalisation of capital flows, and which has also been hit the hardest during the May-June 2006 turbulences. The paper analyses the recent turbulences in the global economy and their consequences in the emerging markets as a case study to illustrate the endogenous formation of expectations. The recovery in Turkey after the turmoil is not based on a solution to the structural causes of the problem, since it has completely depended on the reversal of the capital outflows thanks to high interest rate, but the continuity of this game is far from clear.

$J E L$ classifications: $E_{I 2}, E_{22}, E_{25}, F_{32}, G_{32}$

Keywords: financial fragility, boom-bust cycles, post-Keynesian, distribution, Turkey

\section{Introduction}

Many developing countries shared the common destiny of financial crises in the I99os and 2ooos after the liberalisation of capital accounts in spite of the differences in the former

* Vienna University of Economics and Business Administration. The paper received financial support from the »Dr. Heinz Kienzl Prize« granted by the Austrian National Bank and the Vienna University of Economics and Business Administration. The author is grateful to two anonymous referees and Erinc Yeldan for helpful comments on an earlier version of the paper.

Correspondence Address:

PD Dr. Özlem Onaran, Vienna University of Economics and Business Administration, Dept. of Economics VWL 9, Nordbergstrasse I5, UZA4 3. Stock Kern D, A-Io9o Vienna, Austria, e-mail: ozlem.onaran@wu-wien.ac.at

Received 2 Feb 2007, accepted Io May 2007

(C) INTERVENTION 4 (2), 2007, 353-374 
development policies as well as liberalisation processes. Five years after the latest crises in Turkey and Argentina in 200I, the emerging markets were affected by the global turbulences in the world economy in May-June 2006, when the US Federal Reserve Bank increased the interest rate, and masses of international investors fled out of the emerging markets. The turmoil calmed down after a few months, but the short-term memory of the investors, which has recorded the risks involved in the global financial markets, may shape expectations in the future. The critical question is thus: "can it happen again?«, as Minsky formulated the question in his seminal paper on the US. The post-Keynesian theory as well as historical evidence unfortunately suggest that it is not a question of if, but of when and how deep. This paper addresses this question based on the case of Turkey, which has experienced two severe crises in 1994 and 2001 after the liberalisation of capital flows, and which has also been hit the hardest during the 2006 May-June turbulences.

From Latin America to Asia, financial capital flows have generated simultaneously phases of boom and systemic fragility, which then were typically followed by a bust. The bust phase has been an endogenous outcome of the boom phase in the sense that the fragility of the economy is a result of the "success" of the system. The length and depth of both the boom and bust phases may vary depending on the size of the vulnerability and the shock. But expectations, whose evolution is not easy to forecast, play an important role.

Although the systemic fragility can be prevented by limiting the area of risk taking behaviour, thus regulating the financial markets, financial liberalisation creates interests that also prevent the regulation of these markets. In that sense the boom-bust cycles are not neutral with regard to distribution. The paper addresses the distributional consequences of the crises for Turkey.

The paper is composed of seven sections including this introductory one. Section 2 describes the hypothesis of systemic financial fragility and the boom-bust cycles in the developing countries, which have opened up their economies to international capital flows. Section 3 discusses the historical evidence from Turkey, as a case to illustrate the boombust cycles discussed in Section 2. Section 4 analyses the recent turbulences in the global economy and their consequences in the emerging markets as a case study to illustrate the endogenous formation of expectations. Section 5 discusses again the effects of the global turbulences on Turkey. Section 6 analyses the effects of crises and exchange rate volatility on functional income distribution in Turkey. Finally, the concluding section comprises the policy implications of the analysis.

\section{Boom-bust Cycles in the Developing Countries}

This section presents the mechanism of the boom-bust cycles in the context of domestic and international financial liberalisation. The underlying theory is an open economy extension of the post-Keynesian systemic financial fragility and instability hypothesis of Minsky (1982 and 1986). Based on the analysis of the currency crises since the 1997 Asian crisis, Arestis/Glickman (2002), Schroeder (2003), Foley (2003), Dymski (1999), Kregel 
(1998), Taylor (1998), and Isik (2004) have presented a Minskyan analysis of the financial crises in the developing countries.

The boom and bust cycles are based on the linkages between financial and real variables, and develop endogenously out of the normal functioning of the economy. If good performance persists, lenders become more optimistic and are willing to hold more risky assets or firms, which plan investment in physical capital, accept higher debt levels. The debt/equity ratios increase and firms engage in speculative financing patterns based on short-term financing of long-term investment projects. The asset price booms during such episodes lead to an increase in the value of the collaterals and make it easier to borrow. However, this process makes the firms vulnerable to credit availability and interest rate shocks, which leads to financial instability. In times, when there is a negative shock, and expectations evolve in a pessimistic direction, this fragility leads to a crisis through credit crunch, debt crisis, and bankruptcies. The fragility is latent, but a shock turns it into a crisis. The source of the shock, which causes the crash, is not important. It is the built-in vulnerability that leads to a significant effect of the shock.

Four properties of expectation formation play an important role in this process. First, expectations are formed under fundamental uncertainty and, therefore, agents are influenced by conventional wisdom, such that every investor - dealers as well as firms - in the economy is trying to guess what the other agents will guess. What is crucial is investor sentiment, not fundamentals. Second, competitive pressures among firms or fund managers push them to take similar risks, even when they would rather like to be more conservative. Thus conventional wisdom, i.e. expectations, is also competition-coerced (Crotty 1993). Third, expectations are self-fulfilling. A phase of optimism leads to gradually more boomeuphoric expectations, increasing the risk appetite of the financial investors as well as firms planning investment in physical capital. Fourth, expectations are endogenously evolving, and not static. Thus evaluations about what is reasonable change. Good times lead to a self-propelling adventurism and as expected profits are realised, investors become more self-confident in taking risks. But the opposite mechanism also works. Over-optimism increases financial fragility, and finally, when an adverse shock comes, this fragility becomes visible to the investors. The shift to over-pessimism makes an expected crisis come true. After the crash and crisis, the investors will be cautious for a while, but eventually, after enough time has passed, competitive pressures and new search for profitable investment will start a new endogenous cycle of stability, to be followed by instability again.

In the developing countries, the boom-bust cycles were triggered by both domestic and international financial liberalisation. First the domestic financial markets were liberalised. The increases in the real deposit and loan interest rates and the deregulation of financial institutions set the initial conditions for the formation of fragility. Riskier credit supply by the banks, a shift to financial investments at the expense of physical investments by the investors, short-termism, and an adverse-selection towards riskier projects with a higher expected return have been the outcome (Grabel I995).

When the international capital flows were liberalised at a later stage, high domestic interest rates attracted high capital inflows, thanks to a high financial arbitrage between 
the interest rate and exchange rate due to initially low expected depreciation. Most of these capital flows to developing countries have been portfolio investments or short-term credit. As capital inflows trigger growth in a country, boom-euphoric expectations and competitive international pressures lead to further capital inflows. However, this leads to the appreciation of the local currency, which in turn results in an increasing foreign trade deficit. In the meantime, in addition to the maturity imbalances of an economy without international capital flows, currency mismatches in the firms' balance sheets, which borrow in foreign currency and invest in domestic currency, create new sources of fragility. The high domestic interest rates compared to the foreign currency interest rates and the low expected depreciation rate of the currency is the motivation behind this financing pattern. The public sector may also be highly indebted as was the case in Turkey, but this has not been the situation in many other cases, like the Asian countries. As risks build up and, in particular, currency appreciation and the consequent current account deficit increase beyond a critical point, international investors become slowly aware of the problems. However, this critical point also may change endogenously. The combination of some adverse shocks like the bankruptcy of a firm or a bank, or problems in the export markets, neighbour countries, world economy, or in the domestic political arena may turn this awareness into a speculation about a possible devaluation. The central bank may increase the interest rate in order to avoid capital outflow and to satisfy higher risk perceptions regarding expected depreciations. However, this intensifies the debt problem in the meantime. Finally, the conventional wisdom starts to evolve towards pessimism and investors decide to leave the country before everybody else does. In the end, an expected depreciation becomes a self-fulfilling prophecy. Imported input costs increase due to depreciation with a pass-through effect on inflation. This cost shock and high interest rates lead to bankruptcies, credit crunch, and recession. The debt problem becomes magnified by economic recession and depreciation.

\section{Boom-bust Cycles in Turkey: 1989-2005}

Turkey liberalised its capital account in 1989 as the second stage of its integration into the world economy, which was initiated in 1980 via an orthodox structural adjustment program. The earlier stages had included liberalisation in domestic financial markets along with foreign trade liberalisation, goods and labour market de-regulation. The capital flows consisted mostly of volatile portfolio investments and short-term credit, with the share of Foreign Direct Investment (FDI) in total financial account being limited to a range of IO-20 percent apart from a couple of exceptional years of FDI, like 1989, 2002, and finally 2006. The first wave of capital inflows ${ }^{1}$ reached an annual level of 3.7 percent of GNP in 1993, accompanied by an appreciation of the currency by a cumulative rate of 47.4 percent in real terms in five years as of 1993 compared to 1988 , and a current account deficit

I Financial account plus net errors and omissions, the latter represents unrecorded capital flows. 
of 3.5 percent of GNP. Figure I below portrays the boom-bust cycles in Turkey by illustrating the capital inflows/GNP ratio, the current account balance/GNP ratio, and growth of GNP. Figure 2 (p. 358) shows the annual percent change in the real trade weighted effective exchange rate (deflated by the Consumer Price Index [CPI]).

Figure I: The Boom-bust Cycles in Turkey, 1984-2006*

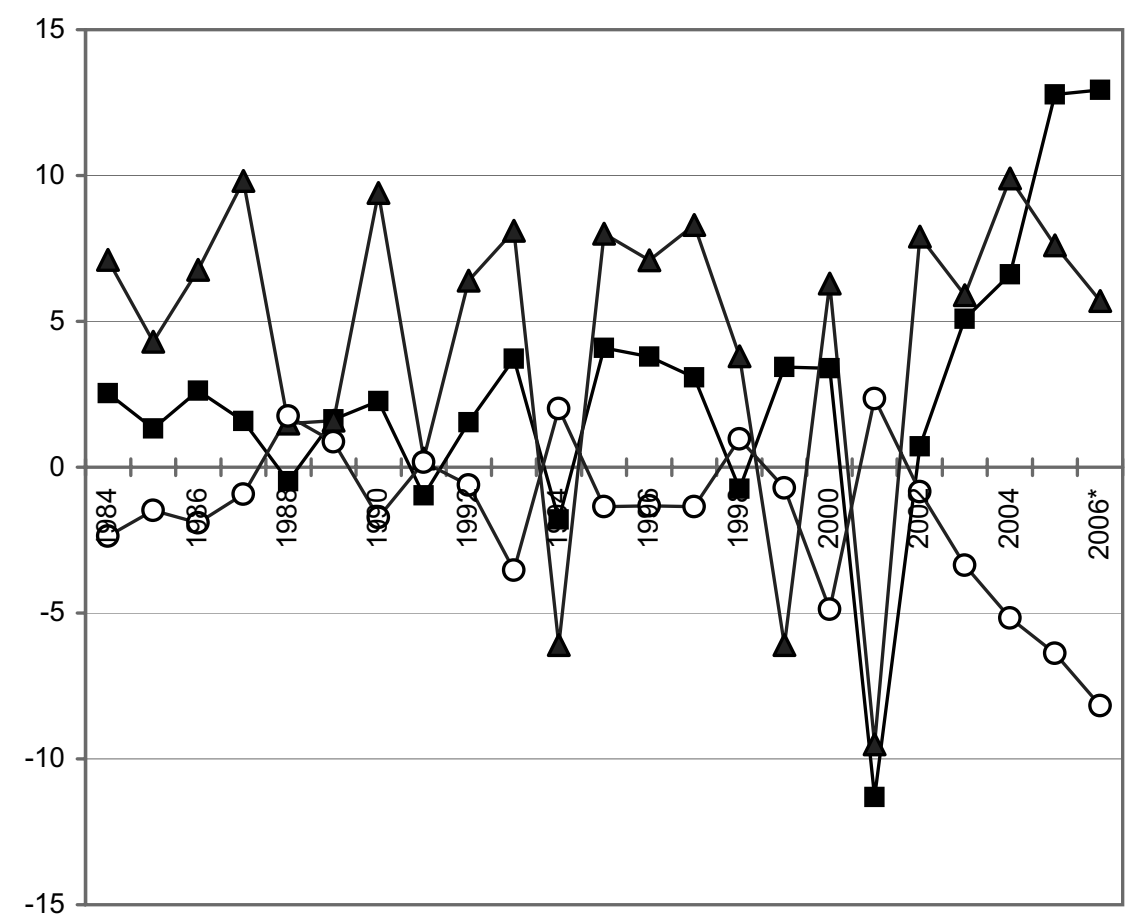

$\neg$ - Capital inflows/GNP (\%) $\longrightarrow$ - Growth (\%) $\multimap$ - Current Account balance/GNP (\%)

* 2006: The cumulative values of the last I2 months where data is available, i.e. October $2005-$ September 2006.

Source: Own calculations based on data supplied by the Central Bank of Turkey, Electronic Data Distribution System.

The accumulated risks associated with an appreciated currency, high current account deficit, combined with the mismanagement of the domestic borrowing policy by the government, who had the infeasible obsession to try to reduce the interest rates in the eve of the elections, ended up triggering a massive capital outflow in $1994{ }^{2}$ This first currency crisis after the liberalisation of the capital account led to a depreciation of the currency by 23.9 percent in one year and a severe recession with GNP declining by 6.I percent.

See Yenurk (1999) for a more detailed discussion of this period. 
Figure 2: Real Exchange Rate Index (Annual Change in \%, Trade Weighted Effective, Deflated by CPI, I989-2006*)

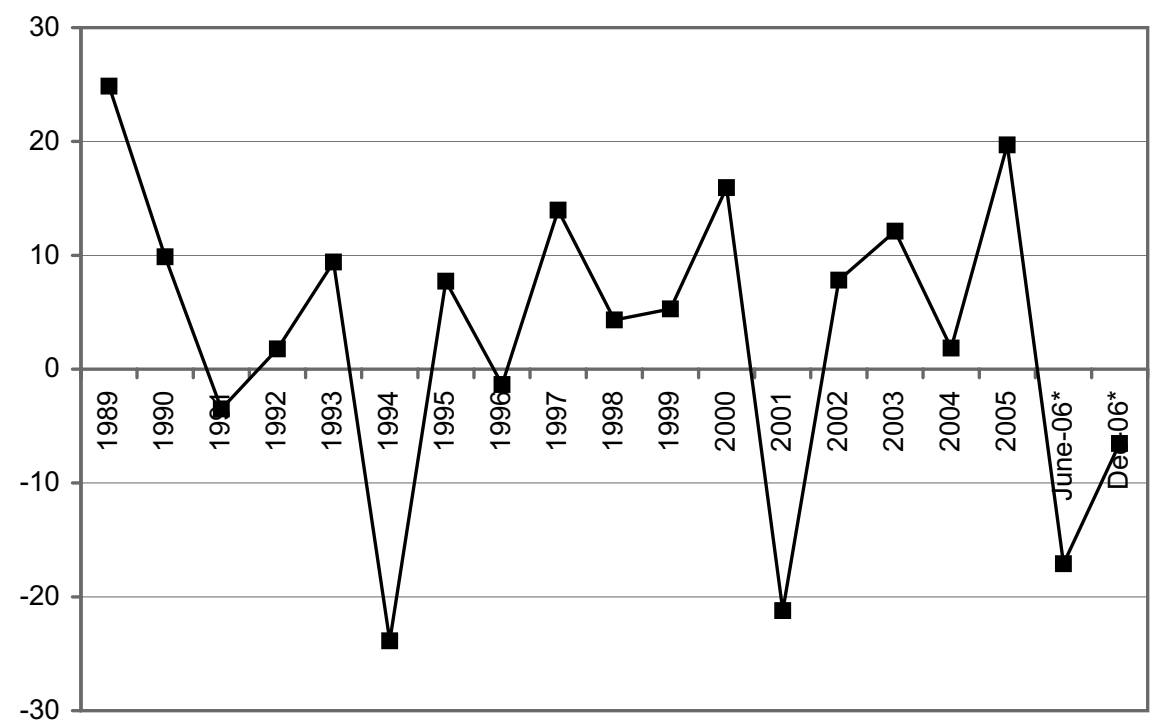

* To indicate the May-June shock the change in \% both in June and December 2006 are shown with respect to December 2005.

Note: $1995=100$, a decline indicates depreciation.

Source: The Central Bank of Turkey, Electronic Data Distribution System.

It did not take long until the international investors started to enjoy the deflated asset prices in the stock and bond markets and the security that came with the already depreciated currency. The ratio of capital flows to GNP reached a level of 4.I percent in 1995 and remained mostly high during theI995-2000 period. In the meantime, Turkey enjoyed high growth rates except for the year of the real (not financial) earthquake of I999. However, the hike in the inflation rate (in CPI) to a level of 125 percent during the 1994 crisis had led price increases to stick to a new higher plateau of 78.7 percent average annual inflation in the following years (1995-1999), compared with a previous average of 66.6 percent (1989-1993). At the end of 1999 the government decided to implement an anti-inflation program within the context of a stand-by agreement with the International Monetary Fund (IMF). The program was based on a crawling peg exchange rate regime, using the exchange rate as a nominal anchor to curb inflation. ${ }^{3}$ However, experience in 2000 proved that the exchange rate as a single nominal anchor was only partially successful to control inflation, as had also been the case in many other countries, and the decline in inflation was not enough to prevent a significant real appreciation of the currency, I5.9 percent in one

3 See Yeldan (2002), Boratav/Yeldan (2006), Akyuz/Boratav (2003), Uygur (200I) for a more detailed discussion of the programme. 
year. At the same time the current account deficit reached to 4.9 percent of GNP, which was higher than before the 1994 crisis. The guarantee of a low and controlled rate of depreciation coupled with high interest rates had attracted capital inflows for the first ten months of 2000 , but the questions regarding the sustainability of the current account deficit accompanied by financial risks in the private banking sector invited a series of pessimistic speculative expectations. Finally, an initial outflow of capital in November 2000 after a liquidity crisis related with a bank was followed by a more massive outflow in February 200I, the latter of which was also triggered by the political conflicts around the issue of banking reform and supervision. The political factor played the role of an exogenous catalyst in a fragile economy, where the investors were already waiting for a signal to move out. But even in the absence of a political conflict, there could have been another triggering event, once the fragility is there. The overall capital outflow in 200 I amounted to II.3 percent of GNP; currency depreciated by 2I.2 percent in real terms in one year, and GNP decreased by a historically high rate of 9.5 percent.

A brief balance sheet of the growth performance of Turkey during this period shows that the high volatility and crises have also led to a lower GNP growth rate (three percent annually) during the first decade of international financial liberalisation (I990-200I), compared to the i980s (four percent per year). It must be also noted that the growth performance after the implementation of the export-oriented structural adjustment program is in general lower than in the previous decade of import substituting industrialisation (4.8 percent per year during 1970-1979).

The dramatic financial crisis of 200 I set the conditions for a long postponed restructuring process in the banking sector. This has also been in line with the preferences of the large scale financial-industrial corporations, which were already competitive in the international markets and wanted to prevent the systemic fragility created by the weak elements in the banking sector, which were not able to cope up with the international standards of making business (Gultekin-Karakas 2006). The Independent Banking Supervision Institution took over the banks, which had operated without obeying the banking regulations, and restructured these banks using public funds to eventually sell them. This process also resulted in a significant entry of international banks into the sector. Through the course of this reform process, the law for the independence of the central bank was also passed, and the monetary policy target gradually evolved towards inflation targeting with a flexible exchange rate system.

In the period after 200I, the EU also turned into a more important anchor in partnership with the IMF to determine the direction of change as well as to signal the credibility of the programs to the international investors (Onis/Bakir 2005, Atac/Grünewald 2006). The targets of IMF programs and the steps to be taken to fulfil the economic conditions of membership overlapped. In terms of the international institutions, which audited and supported the credibility of the economic programs that Turkey implemented until the 200os, the IMF had been the only anchor. Even after Turkey started the Customs Union with the EU in 1996, or after the Helsinki Summit in 1999, where Turkey was accepted as a candidate country, the EU played a role more as a political anchor; and a sort of an implicit division of labour was made with the IMF for auditing economic restructuring. 
The conditional green light to start accession negotiations in the 2002 Copenhagen summit has been effective in turning EU to a more extensive anchor.

After the crisis of 200I, Turkey enjoyed an uninterrupted and high growth era, with a 7.5 percent average annual rate of growth in GNP during 2002-2005. High capital inflows towards Turkey among other emerging markets have been the determining source of finance for achieving this growth rate. This is to some extent similar to what had happened after the 1994 crisis. Thanks to the deflated prices in the asset markets, the depreciation of the currency lowered asset prices once again in terms of foreign currency and also decreased the likelihood of a depreciation in the coming period, creating the possibility of an appreciation after the over-shooting of the exchange rate. Additionally, the EU-anchor was a significant factor in securing the capital flows in the period after 200I. The result was typically a continuous appreciation in currency; at the end of 2005 the Turkish lira (TL) was 47.4 percent appreciated compared to 200I; and the current account deficit had reached a historically high level of 6.4 percent of GNP. Nevertheless, talking about the risks associated with such a high current account deficit seemed to be a complete pessimism at that time. The market sentiments celebrated this period as a completely new era, where the EU-anchor was playing an important role in decreasing political risks, and creating the potential for a higher FDI inflow. The optimists also emphasized that the current account deficit was financing new private investments, which would eventually improve competitiveness and exports. The government mostly cited the effect of increasing oil prices as an excuse for the increase in current account deficit, and seemed to be particularly trusting the corrective capacity of the flexible exchange rate system to tame speculative expectations.

\section{2006 and Global Turbulences}

The optimism about the start of a new era in the Turkish economy was disturbed by the global turbulences in the world economy in May-June 2006. Overall, between May 8 and June $\mathrm{i} 3$, emerging stock markets lost a quarter of their value. Within two weeks time after the initial international shock in May II, the Turkish currency depreciated by 7.7 percent in real terms, and the trend continued in June with a cumulative real depreciation rate of 17.3 percent at the end of the month compared to April. Between May Io and June 30 , the Istanbul Stock Exchange Index fell by 32.3 percent in terms of US dollars. During the same period Hungary, Brazil, and South Africa were also among the emerging markets, which were hit most severely. But the outflow of capital was not particularly selective or related to the so-called »macroeconomic fundamentals«, with India, for example, also being one of the most affected countries in spite of its almost negligible current account deficit. Among the new member states of Europe, in addition to Hungary with its seriously high current account deficit, Poland and Slovakia were also affected. ${ }^{4}$

4 See Onaran (2006a) for an early article on the leading indicators of fragility in the Central and Eastern European new member states and Turkey. 
One could say that the May-June turbulences were single, exceptional, and temporary events. However, the swings in the mood of investors are worth analysing as an insightful case on how expectations are being formed and what consequences they could have in the future. The flight of international financial investors out of the emerging markets is explained mostly by the fear that rising interest rates and the slowdown in the US economy might ultimately upset the delicate "harmony«of the global economy. ${ }^{5}$ This expectation for higher volatility in turn leads to dwindling appetite of investors for risky assets. The Economist (2006a: 79f.) writes that some analysts ascribe the change of mood to a "sudden dislike of risky assets, as if investors had woken up on May $\mathrm{II}^{\text {th }}$ with pressing need to dump Brazilian shares or copper futures and buy something safer". But the fact that the outflow of capital in May-June did not positively discriminate the bulk of the developing countries, which have been correcting their budget and current account deficits after years of painful experiences throughout the Mexican, Asian, and Russian financial crises has even worried The Economist, the cheerful defender of de-regulated financial markets:

"Indeed, rather than raising doubts about the emerging economies, the stock market excesses perhaps raise doubts about the markets themselves [...] [T] his is simply a sign of the sheer weight of money moving in and out of markets that are still too thin to bear it comfortably. This makes the flow of foreign money sirrelevant at best, extremely dangerous at worst`, according to one asset manager.« (The Economist 2006a: 79f.)

Another insightful description of the reasoning of the investors, as they shift from optimism towards pessimism, is given by Larry Elliott of the Guardian Weekly, writing about the spill-over effects of an earlier currency crisis in Iceland in March 2006:

"Iceland is a country that rarely makes the business pages. [...] But when the rating agency Fitch downgraded Iceland's debt, it sent ripples through the markets. Hang on, dealers said; didn't the Asian financial crisis of 1997 start with a balance of payments problem in a country that previously had barely blipped on to the radar screen? The lesson of Thailand nine years ago was that the beating of a butterfly's wing can have powerful and costly consequences. As a result traders took one look at what was happening in Iceland and dumped the currencies of other emerging markets - Hungary, Brazil, South Africa.« (Elliot 2006: 8)

The May-June 2006 turbulences were short-lived in the sense that the investors soon started to enjoy the low asset prices even in the riskiest markets like Turkey after the initial panic. Attracted by the higher interest rates in Turkey compared to elsewhere (in US dollar terms), aggressive risky investment behaviour looked for reasons to explain why the mechanism will not break down, the coercive competitive pressures led the conventional wisdom to shift again towards buoyancy. Indeed it was defined as »a bit of profit-taking" by The Economist (2006b) afterwards, and this did seem to be rational to do in order to

For a much earlier paper on the issue before the turbulences, see Goldstein (2005). 
gather the potential profits due to the unforeseen increases in the emerging market share prices during the last couple of years. The Economist (2006b: 74) also changed its evaluation of the financial flows in a month's time by calling what happened "a drama not a crisis", and writing that this is perhaps

"a measure of the growing maturity of emerging markets that before anyone could coin a name for (inevitably terming it a `crisis`) a recovery of sorts had begun."

A kind of a consensus also exists that there is only real reason for concern if one believes that the world is going into a global recession. But until now this is a possibility that the market professionals have to rule out in order not to shift to overly conservative investment practices too early in time. Because that would then make them deliver lower profits to their customers compared to their competitor dealers, who have a higher risk appetite.

Going back to our original question about understanding the formation of expectations in the international financial markets, we can now assess whether expectations are rational and based on fundamentals, or whether they are norm determined and swing along with the ups and downs in the "sentiments" and "appetite" of the investors. It is already raising doubts about the objectiveness of the expectations, when the descriptions of the markets in the business press start sounding like a doctor describing a case of psychiatry, using words like "the mood of the markets", "nervous«, and "tense«. The evaluations are usually not linked to the so-called fundamentals of the economy. And the critical values for leading indicators of crisis such as the current account deficit/GDP ratio change through time, or new sources of fragility like private sector indebtedness are not considered. But finally, as the optimistic conventional wisdom shifts towards conventional panic, triggered by an ever changing critical turning point in the risk indicators or a political conflict or a global event, the endogenous cycles of over-optimism and over-pessimism generate parallel cycles of stability and instability. What this means for the world economy and the developing countries in the next years will depend on how quick the global savings imbalances will be corrected, how deep the accompanying US recession will be, and last but not least, how the markets will perceive the consequences of it for the developing countries.

\section{Turkey Amid Global Turbulences: To Learn or Not to Learn From History}

As discussed in Section 3, Turkey was already in a fragile position in terms of its dependency on the capital flows due to its high current account deficit, and the appreciation of the currency was at risky levels. However, this position was not shared by most of the analysts. For example, The Economist (2006c: 78f.) writes that

"when Joseph Quilan, a strategist at the Bank of America Capital Management described Turkey in March as sthe weak link in the merging market chain`, few investors listened«. 
However, then in the period after May II, »his words have sounded prophetic. Turkey has been among the hardest-hit of emerging markets since May II«. Some analysts perceived of this shock as "just a correction", which may help to restore equilibrium. Regarding the turmoil that followed, many like Sonal Desai, an economist at Dresdner Kleinwort Wasserstein, suggested that "what we are seeing in Turkey is pain for investors, not a crisis of the economy« (reported by Boland 2006a: 7). It was also argued that

»investors might have just wanted to cash in their spectacular profits they had made from the start of 2006 until then" (The Economist 2006c: $78 \mathrm{f}$.).

But once those profits were realised, and the short-term memory of the market players also recorded what might happen when markets act in herd behaviour, the vulnerability of the economy of Turkey started to receive more attention. So, although not long ago most analysts had believed that Turkey had opened a new era, they suddenly started to be more cautious.

Business press started to write about the growing political instability ahead of elections in 2007 , or about the conflicts between the "Muslim Democrat" Government and the military elite, who thinks of the government as a threat to the regime (e.g. Boland 2006b: 6, The Economist 2006c: 78f.). The dispute between Turkey and the EU over Cyprus also started to become an issue more often in the business press. However as Serhan Cevik, an economist at Morgan Stanley, says, there is not "any reason why the country's political risk should be higher now than it was a year ago" (reported by Boland 2006a: 7). But then, the more surprising and scary point might be "that investors remained sanguine for so long", as The Economist (2006c: 78f.) more cautiously suggests.

Indeed regarding economic policy the government has followed a solely neo-liberal program, as also supported by the IMF and the EU (Independent Social Scientists 2006, Voyvoda/Yeldan 2005, Yeldan 2007). Economic policy in general is a rather conflict-free area between the government, business circles, and the military elite, despite the political conflicts between them. ${ }^{6}$ Even if the IMF raised doubts about the Value Added Tax (VAT) cuts and its implications for the primary budget surplus during its visit to review a loan agreement (which unfortunately had also coincided with the most turbulent days in May), thus a time when more supportive IMF declarations could have been expected in order not to disturb the credibility of the economic program, the government is expected to achieve a significantly high primary budget surplus of 6.5 percent of GNP in 2007 , and the same figure for 2006 is expected to be even higher, 7.4 percent (State Planning Organisation 2006). So why were the doubts being raised in spring 2006 but not before? Were the political risks making the country more fragile than other emerging markets, as analysts would suggest, who believe that markets would have worked efficiently, if only the

6 The conflicts about the appointment of the central bank president ealier in 2006 may sound like conflicts over economic policy. But indeed, rather than being disputes over the content of the policies, these are power struggles of the government to build its own bureaucratic cadres, which in turn provokes fears in the old established business circles and the ruling elite. 
politicians were in full harmony? Our explanation would be rather the other way around: The market analysts ignored both economic and political risks, which had been there for the past years, under competitive pressures to enjoy the high returns in this risky market. And by doing so, they have also made aided fragility in terms of higher appreciation rate and current account deficit. And now, due to the sudden change in conventional wisdom and risk "appetite in response to the external shocks coming from the US economy, they started to spot out the risk factors in Turkey and elsewhere in the emerging markets. Understanding this process of expectation formation becomes quite relevant, if we look back to the consequences of the global turbulences in May 2006 in Turkey and the remaining points of fragility.

The capital inflows, which had reached to historical highs during the first four months of 2006, were tamed during May-June 2006 due to the outflow of portfolio investments. However, this outflow was already more than off-set by inflows of FDI and other financial investment. When the storm was over and the central bank also helped to calm down the markets by raising the interest rate, portfolio investment flows also recovered. Overall total capital inflow remained high in 2006, leading to an inflow more than needed to finance the 8.2 percent current account deficit of GNP (according to the latest announced figures of GNP in September 2006; the ratio is estimated to be eight percent at the end of 2006).

After the May-June turmoil, the initial hike in the exchange rate was slowly, although not fully, reversed during summer 2006, but Turkey remained fragile to other shocks afterwards. During the political turbulence in Hungary and Poland in September, the TL nominally depreciated by 6.I percent against the euro in one week (September 19-25), which is even more than the depreciation in forint (2.3 percent during September I8-22) or zloty ( $\mathrm{r} .3$ percent). Even the military coup in Thailand, political turmoil in Brazil, the declarations of the new president in Ecuador during his electoral campaigns on debt default made it all to the headlines, leading to downswings in the financial markets in Turkey. The decision of the European Commission about a partial suspension of accession negotiations with Turkey, due to the Turkish refusal to open its ports and airports to Cypriot vessels and planes in compliance with the Ankara Protocol, was a source of further uproar for the exchange rate. As of December 2006, the TL has depreciated by 6.5 percent in real terms compared to 2005 (figure 2), but is still 37.7 percent appreciated compared to 200I. The effect of the small "correction« of the markets in 2006 on the current account deficit is yet to be seen.

In the meantime the central bank responded to the increase in »risk appetite of the markets by increasing the lending rate from 16.25 percent in April to 22.5 percent in four steps. The average interest rate (annual compound) in the government debt instrument (GDI) auctions increased to a level of 22.0 percent at year-end from a level of I4.I percent in April 2006, and the average maturity of monthly borrowing also declined from 810 days in April to 427 days in December. The unpleasant remembrance of a possible turmoil in the short-term memory of the investors prevented a correction of the interest rates downwards, as had been the case in the exchange rates. 
The depreciation of the TL in May-June 2006 had a quick and significant pass-through effect on inflation, due to the rise in the cost of imported inputs in a highly import dependent economy. Inflation at the end of the year reached a level well above the five percent target. Eventually, Consumer Price Index (CPI) inflation increased from 7.7 percent to 9.6 percent, and the Producer Price Index (PPI) inflation from 2.7 percent to II.6 percent in 2006 compared to 2005 .

With respect to the real economy, the risks of dependency on volatile international flows were already demonstrated by the immediate slow down in growth in the third quarter of 2006 to a rate of three percent, from a growth rate of 7.7 percent in GNP in the first half of 2006. The growth figures, which turned out to be well below the forecasts of the market analysts, indicate that the effect of the May-June turbulences on the real economy has been more severe than expected (Yapi Kredi Bank 2007). The source of the slow down has been the service sector, which implies that the lagged response in industry and construction can further the slow down in the following periods. On the expenditure side the quick reaction came from the consumption demand, and the effects on investment are yet to be seen once the firms complete their previously planned investment projects.

In order to understand the full potential of the real effects of further exchange rate volatility in the future, a closer look at the investment and financing behaviour of the nonfinancial business sector is important. Formerly, fragility in Turkey had been mostly based on the budget deficits of the public sector, the current account deficits, and the open foreign exchange position of the banking sector. In 2007, public budget deficit is quite under control; the banking sector seems to have learned to hedge its foreign exchange risks ${ }^{7}$ based on the lessons learned from the $200 \mathrm{I}$ crisis. However, this time it is the private nonfinancial business sector which is exposed to a significant degree of foreign exchange risk. Indeed this shaky finance strategy is the risk that is hidden behind the apparently successful investment performance of the private sector. It is true that private investment in both machinery and construction has been recovering from the effects of the $200 \mathrm{c}$ crisis as well as the former downward trend since the 1999 earthquake (see figure 3, p. 366). Particularly the increase of investment in machinery and equipment is the source of the hope that investment in new capacity will also help to improve the Turkish productivity and international competitiveness, although it has stagnated at a level of 9.5 percent of GNP since December 2006 and is still below its peak in 1997. Yet this increase in investment is financed by increasing indebtedness of the private sector, particularly in foreign markets. Figure 4 (p. 367) shows the changes in the foreign debt of the public versus the private sector as a ratio to GNP.

Although the public foreign debt/GNP ratio has decreased to 21.8 percent as of September 2006 from its $200 \mathrm{I}$ level of 48.8 percent, the private foreign debt/GNP ratio is still as high as in $200 \mathrm{I}$ with a level of 29.6 percent. And not only the long-term but also the short-term private debt are increasing. The total foreign debt to GNP ratio is overall at a very high level of 51.4 percent, making the economy susceptible to exchange rate shocks. 
Figure 3: Private Investment/GNP (in \%, 1987-2006*)

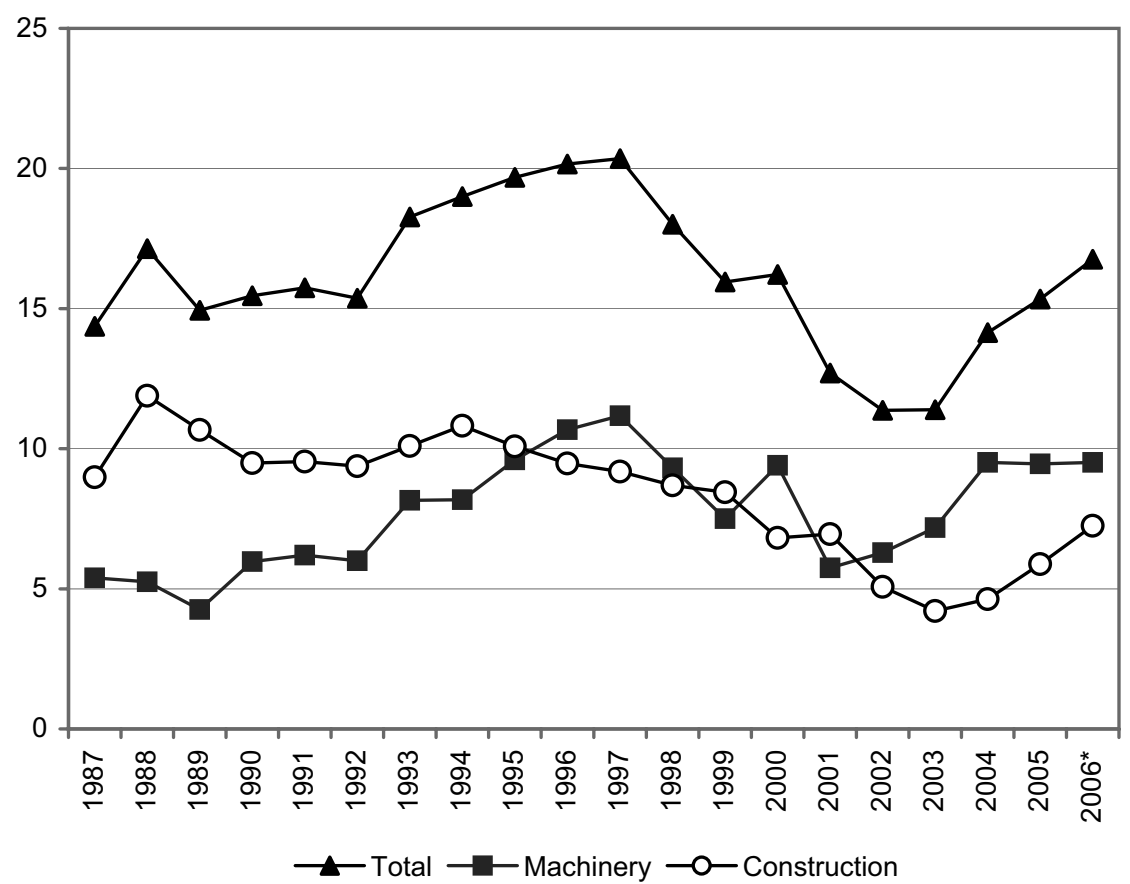

* 2006: The cumulative values of the last I2 months where data is available, i.e. October 2005-September 2006.

Source: Own calculations based on data supplied by the Central Bank of Turkey, Electronic Data Distribution System.

Finally, figure 5 (p. 368) shows the short foreign exchange position of the non-banking sector as a ratio to GNP, international reserves, and exports of goods and services. All three ratios point at the increasing relative size of the short position of firms. The ratio of short foreign exchange position of the non-banking sector to exports of goods and services has increased from 28.I percent in December 2005 to 39.8 percent in September 2006, indicating increasing currency mismatch in the balance sheet of firms. Moreover, the central bank has been pointing at the fact that this aggregate figure hides the heterogeneity among the firms in the sense that the risks would be much higher for firms with low export revenue, which have failed to hedge their borrowing with future income. These developments make the issue of the sustainability of capital flows and exchange rate vital for Turkey.

Next to increased potential to export with a higher domestic investment performance, the increased FDI inflow is another source of optimism. It is argued that it could prevent the potential risk of a larger currency depreciation, since a high FDI inflow to finance the current account deficit can be perceived as a positive development, decreasing the amount of finance to be maintained in the international financial markets. FDI consti- 
Figure 4: Foreign Debt of the Public and Private Sector as a Ratio to GNP (\%) (left scale: total \& public; right scale: private)

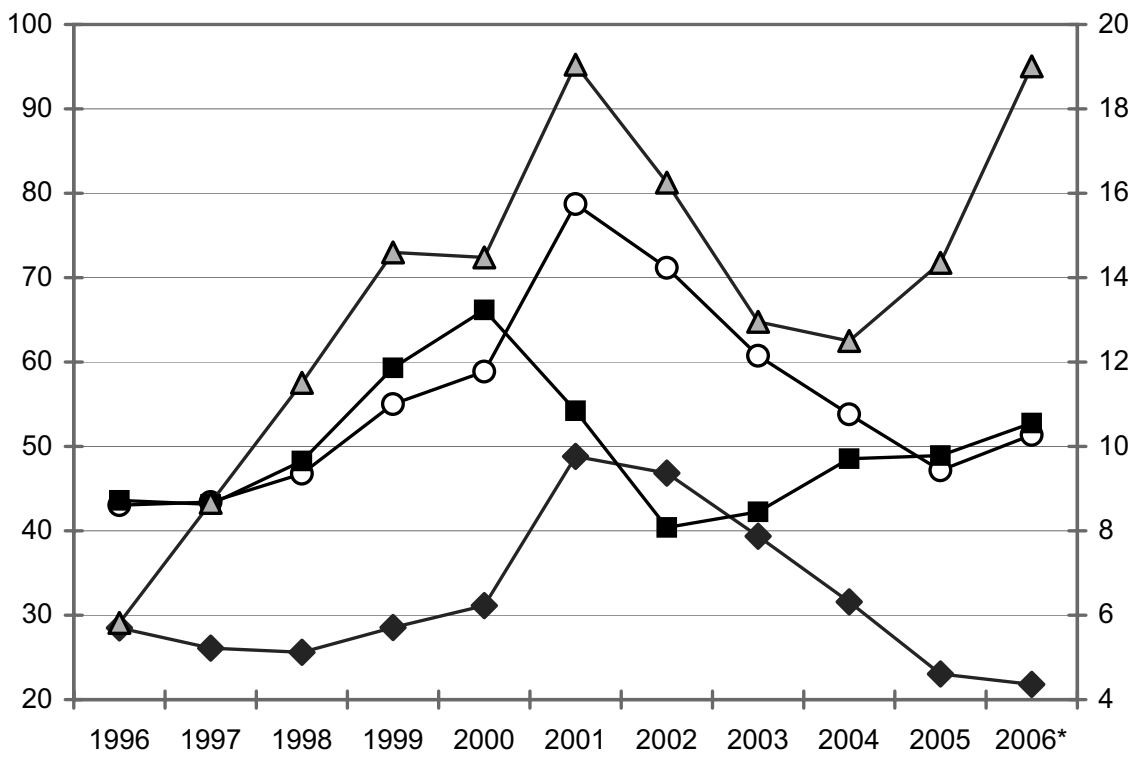

$\multimap-$ Total foreign debt/GNP $\longrightarrow$ Total public debt/GNP

$\rightarrow$ Private short-term debt/GNP $\triangle$ - Private long-term debt/GNP

* 2006: The cumulative values of the last I2 months where data is available, i.e. October 2005-September 2006.

Source: Own calculations based on data supplied by the Central Bank of Turkey, Electronic Data Distribution System.

tuted an important part of the capital inflows with a share of 36 .I percent during the first nine months of 2006, and the EU-anchor did have some effects. FDI inflows from Europe in this period reached up to 92.9 percent. However, the continuity of the inflows remain far from clear, since most of them were through mergers and acquisitions, particularly in the banking sector. The share of the manufacturing sector in total FDI inward stock also remained to be as low as I5.I percent. It is true that the ratio of the stock of FDI to GNP remains to be quite low in Turkey (II.6 percent in 2005) compared to those in the Central and Eastern new member states of the EU (e.g. 55.9 percent in Hungary, 48.I percent in Czech Republic, 3I.I percent in Poland, and even as high as 93.6 percent in Estonia, see UNCTAD 2006). This is often seen as a positive prospect about the possible trajectory of the FDI developments in Turkey. However, it is not clear whether such high rates can be achieved also in Turkey, which has a long tradition of large scale domestic corporations itself. For comparison, the same rate is 27.3 percent in Mexico, with a relation to US similar to that of Turkey to the EU, but a far closer geographical proximity. Finally, there are 
Figure s: Short Foreign Exchange Position of the Non-banking Sector

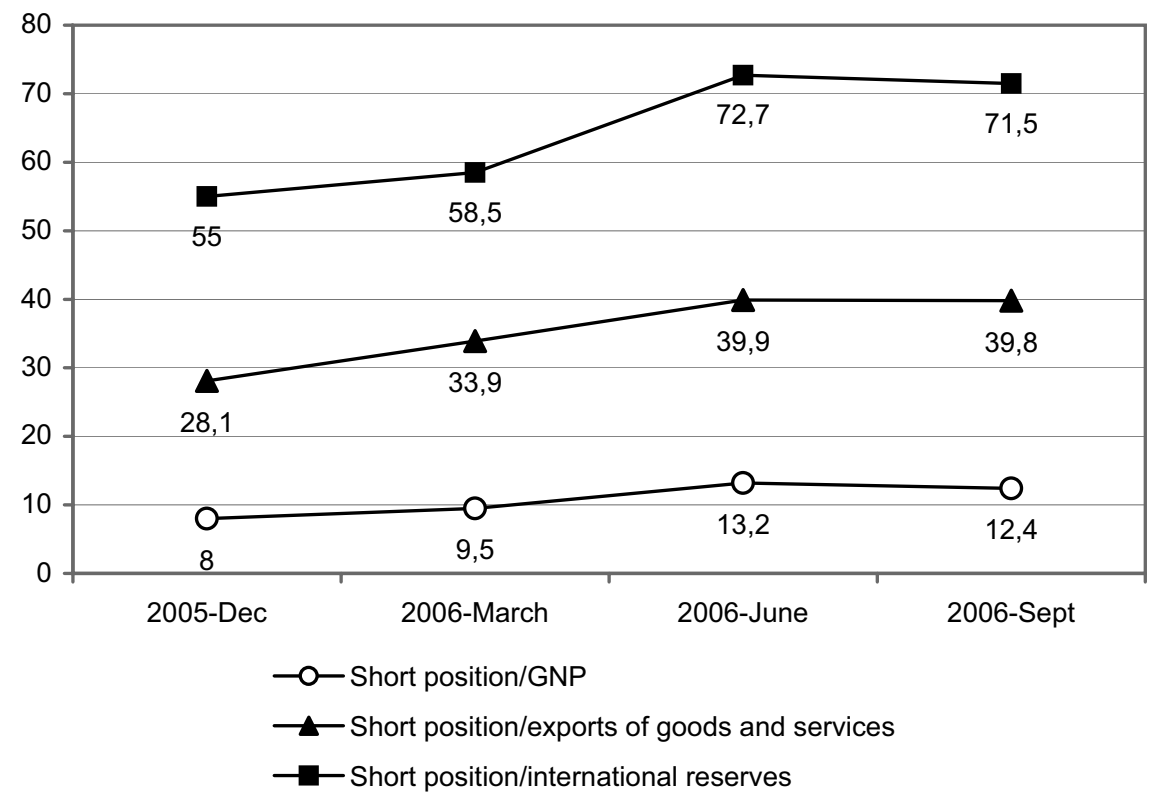

Note: GNP and exports of goods \& services are computed on a yearly basis. International reserves are stock values at the end of period. GNP value of June is used for September. International reserves are gross foreign exchange reserves of CBRT (including gold).

Source: Central Bank of the Republic of Turkey 2006.

doubts that FDI may create a higher level of import dependency due to lack of domestic backward linkages and supply of intermediate inputs from international subsidiaries, rather than contributing to an improvement in productivity and in the longer run in the current account balance. $^{8}$

\section{Functional Income Distribution Through the Boom-bust Cycles in Turkey}

Some domestic and foreign investors can make gains over the boom-bust cycles, buying and selling the domestic currency denominated assets at the right time. When the bust arrives, there are winners and losers of this process, but this is not necessarily a conflict between the shares of financial vs. non-financial profit income in total income. The labour share declines in all countries that have experienced currency crises (Onaran 2006b), and

8 See Görg/Greenaway (2003) for a review of the spill-over effects of FDI, and Mencinger (2003) for a discussion for the case of transition economies. 
this decline in the labour share then compensates for the increase in financial costs for industrial firms. Evidence also suggests that industrial firms find the chance to increase their returns from financial activities (Istanbul Chamber of Industry 2003).

The crises of both 1994 and 200 I have led to a clear and long lasting decline in the wage share in Turkey. Figure 6 shows the wage share in manufacturing industry.9 The percentage decrease in the wage share by far exceeds the rate of decline in production during the crises. After a crisis, employers push workers to accept dramatic wage cuts or compulsory unpaid leaves to avoid job losses. Eventually, profits are restored, and when the crisis is long past it is labour which has carried the burden of adjustment. The crisis also creates a negative effect on the bargaining power of labour for a long period afterwards. Diwan (200I: I) defines crises as episodes of distributional fights, which leave "distributional scars«. Although a strong economic recovery takes place after the crisis, with production returning to its pre-crisis level within a year, the fall in the wage share is much more persistent.

Figure 6: Wages/Value Added, 1970-2005

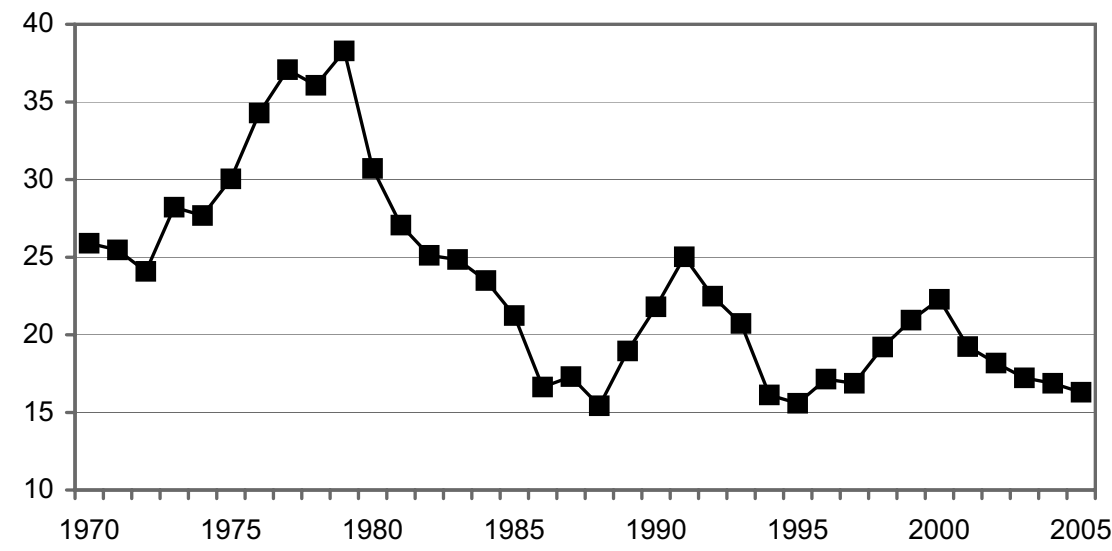

Note: The data for the wage share in manufacturing in the national accounts exist for the period after 1987 at a sectoral level. This data is linked with the data in the Industrial Survey for the period after 200 I due to data availability.

Source: Own calculations based on data supplied by the State Institute of Statistics.

After the crises of 1994, the fall in the wage share continued also in 1995, with a cumulative decline of 24.8 percent compared to 1993. The shock in $200 \mathrm{I}$ was more dramatic; the wage share has continued to decline throughout the next five years including 2005. The

9 Due to lack of long time series data for wages, the analysis here is based on the manufacturing industry. The wage share data for the rest of the economy exists only from 1987 onwards, based on the national accounts. The data used here is reported in the Annual Survey of Employment, Pay- 
initial decline of 13.7 percent reached finally to a cumulative fall of 26.8 percent in 2005 compared to 2000 . The wage share in 2005 is as low as 1994 .

Strikingly, the whole era of Turkey's liberalisation and integration into the world economy since 1980 has been a period of decline in the wage share. Indeed, the major negative shock to labour's share took place in the early phase of neo-liberal structural adjustment and the recoveries in the later stages were minor and short-lived and were reversed by financial crisis. The short period of increase in the wage share during 1989-1991 was interrupted by the 1994 crisis. The recovery after the 1994 crisis was rather slow, with the wage share in 2000 still below the previous peak of I99I.

One important factor that has led to the deterioration in labour's share during the crises is the exchange rate movements. Apart from the crisis episodes, the opening up of the economy was accompanied by significant devaluations of the domestic currency with the aim of achieving higher international competitiveness. Be it due to the official devaluations of the early stages of liberalisation or the market-made depreciations after the financial crises: there is a clear trade-off between the rate of depreciation and the wage share. Depreciation creates an increase in the price of the imported goods, and thus in overall input costs. During the financial crisis depreciation of the local currency creates a significant inflationary shock. The magnitude of this shock is related to the import dependency of the economy, because the oligopolistic power of the firms to pass on import price changes to consumers. But the workers confronted with the threat of job loss during a crisis mostly fail to pass the consequent price shocks to their nominal wages. In the meantime, utilising the imbalance of power relations, the firms compensate the increase in input costs by a decline in labour costs. The reverse of this story has also been true during episodes of capital inflow, and currency appreciation, when employers became more accommodated towards wage demands, e.g. during the episode of 1989-1993. However, this was soon disturbed by the currency crises. Table I demonstrates the effect of a nominal depreciation on the wage share in manufacturing industry, based on a regression analysis. The change in the wage share (in logs) is estimated as a function of the change in nominal exchange rate and the manufacturing value added (both in logs) and the first lags of all the variables. The estimation results indicate that a ten percentage point increase in the

ments, Production and Tendencies in Manufacturing Industry based on firm level surveys supplied by the Turkey Statistical Institute for all public sector firms and private firms with io or more persons for the period of 1950-200I. The wage and salary data in the survey include wages and salaries, overtime payments, bonuses, indemnities, payments in kind, before gross income tax, social security and pension fund premium deductions from the employees, but excludes the contributions to social security etc. by the employers. That is the reason why the wage share looks too low and is not comparable to the levels of the wage share based on national accounts methodology. Due to a change in the survey methodology, the data after 200 is not announced, therefore the wage share based on the manufacturing industry surveys is extended using the percentage change in the wage share in manufacturing industry based on the national accounts for the years 2002-2003. The two series have a correlation coefficient of 0.87 . 
depreciation rate (percent change in the exchange rate) leads to a 2.2 percentage point increase in the growth rate of the wage share. The persistence of a decline in the wage share is also significant. Growth does not have a statistically significant effect either in current or lagged form.

Table I: Estimation Results for the Wage Share in Manufacturing

\begin{tabular}{lcc}
\hline Variable & Coefficient & Prob. \\
\hline C & 0.0008 & 0.9895 \\
DLOG (manufacturing value added) & 0.0037 & 0.9935 \\
DLOG (TL/\$) & -0.2209 & 0.0731 \\
DLOG (Wages/manufacturing value added)t-1 & 0.3293 & 0.0982 \\
DLOG (manufacturing value added)t-1 & 0.3135 & 0.4594 \\
DLOG (TL/\$)t-1 & 0.1364 & 0.2963 \\
R-squared & 0.2300 & \\
Durbin-Watson stat & 2.1435 & \\
\hline
\end{tabular}

Note: Dependent Variable: DLOG (wages/manufacturing value added); method: Least Squares; sample: 1972-2005.

The data necessary to analyse the effect of the recent turbulences on income distribution was not available at the time when this article was written. Both the annual industry surveys and the national accounts based on the income approach, which are the sources of the relevant data, only cover a period until December 2005. But the quarterly manufacturing industry surveys, which report real earnings, even if not value added, indicate only a minor decline of 0.2 percent in real earnings in the third quarter of 2006 compared to the same quarter of the previous year. Given the increases in productivity, this nevertheless corresponds to a decline in the wage share. However it is too early to say much on the further distributional effects, since the wage bargaining process also needs some time to adjust to the shock.

\section{Conclusion}

The global turbulences of May-June 2006 and the massive, though temporary, capital outflows from the developing countries have once again raised doubts about the sustainability of a growth process dependent on capital inflows. The recovery in Turkey after the turmoil is not based on a solution to the origin of the problem, since it has completely depended on the reversal of the capital outflows thanks to very high interest rates, but the continuity of this game is far from clear. A new wave of speculative financial capital outflows from the emerging markets, which may be followed by further turbulences given the global imbalances, remains to be a significant risk factor, particularly for the most 
fragile cases like Turkey. In May, neither the high financial arbitrage nor the EU-anchor has protected Turkey against the capital outflows from the emerging markets. The EUanchor has indeed failed to protect even Hungary, which is a member state. If the conventional wisdom of the markets shifts from optimism to pessimism, can the EU-anchor help Turkey at all, particularly when relations with the EU are getting tenser? Would the markets care whether the appreciation of the currency is a natural catching up phenomenon (Balassa-Samuelson effect), or due to the improved prospects for FDI inflows, which increased investments financed by imports and eventually help the country to cover the current account deficit in the future? The evaluation of the financial investors at critical turning points in the future will certainly depend on the recent history and how badly they were punished by volatility. Now that the boom has been underway for a long time and the recent turbulences have rather had a profit-taking than punishing effect for the investors, a radical shift to over-pessimism can be postponed for another while, although investors are already quite cautious. However, the question is whether this eventuality can be ruled out completely. Simply ignoring the possibility of a massive outflow, which will trigger deeper real effects in the future, seems to be gambling in policy making. This behaviour is like ignoring a gas leakage in your house, and choosing a "wait and see« strategy, rather than trying to fix the leakage. Sound policy requires taking the global turbulences and their consequences seriously and considering them as cases in defence of financial regulation and international capital controls. Financial regulation along with industrial policy is the only long-run policy alternative to prevent financial fragility and the potential causes of a future crisis.

\section{References}

Akyuz, Yilmaz./ Boratav, Korkut (2003): The Making of the Turkish Crisis, in: World Development, Vol. 31, No. 9, pp. 1549-1566

Arestis, Philip/Glickman, Murray (2002): Financial Crisis in Southeast Asia: Dispelling Illusion the Minskyan Way, in: Cambridge Journal of Economics, Vol. 26, No. 2, pp. $237-$ 60

Atac, Ilker/Grünewald, Andreas (2006): Turkey's Political Economy between Crisis and Strong Growth: Discussion of the Europeanisation Dynamics in Turkey, ESA Workshop, Vrije Universiteit Amsterdam, 3r August-2 September

Boland, Vincent (2006a): Turkey Feels Pressure of Plunging Lira; Ankara Faces Tough Rate Decisions If It Is to Maintain Economic Momentum and Keep Its EU Ambitions Alive, in: Financial Times, June 7, p. 7

Boland, Vincent (2006b): Country's Business Elite and Rulers Drift Apart, in: Financial Times, May 23, p. 6

Boratav, Korkut/Yeldan, Erinc (2006): Turkey, 1980-2000: Financial Liberalization, Macroeconomic (In)-Stability, and Patterns of Distribution, in: Taylor, Lance (ed), External Liberalization in Asia, Post-Socialist Europe and Brazil, Oxford: Oxford University Press, pp. 417-455 
Central Bank of the Republic of Turkey (2006): Financial Stability Report, URL: http://www. tcmb.gov.tr/yeni/eng/

Crotty, James R. (1993): Rethinking Marxian Investment Theory: Keynes-Minsky Instability, Competitive Regime Shifts and Coerced Investment, in: Review of Radical Political Economics, Vol. 25, No. I, pp. I-26

Diwan, Ishac (200I): Debt as Sweat: Labor, Financial Crises, and the Globalization of Capital, mimeo, URL: http://info.worldbank.org/etools/docs/voddocs/150/332/diwan.pdf

Dymski, Gary A. (1999): Asset Bubbles and Minsky Crises in East Asia: A Spatialized Minsky Approach, University of California, Riverside, Department of Economics, Research Paper, April

Elliott, Larry (2006): Fair Exchange for Fairer World, in: Guardian Weekly, March Io-ı6, p. 8

Foley, Duncan K. (2003): Financial Fragility in Developing Economies, in: Dutt, Amitava K./ Ros, Jaime (eds.), Development Economics and Political Economy, Cheltenham/ Northampton: Edward Elgar

Goldstein, Morris (2005): What Might the Next Emerging-Market Financial Crisis Look Like?, Institute for International Economics Working Paper Series, No. 05-7

Görg, Holger/Greenaway, David (2003): Much Ado About Nothing? Do Domestic Firms Really Benefit From Foreign Investment?, Discussion Paper Series IZA, No. 94

Grabel, Ilene (1995): Speculation-Led Economic Development: A Post-Keynesian Interpretation of Financial Liberalization Programmes in the Third World, in: International Review of Applied Economics, Vol. 9, No. 2, pp. I27-I49

Gultekin-Karakas, Derya (2006): Rising Concentration and Centralization of Banking Capital in Turkey, Annual Conference of European Association for Evolutionary Political Economy, November 2-4, Istanbul

Independent Social Scientists (2006): Turkey and the IMF: Macroeconomic Policy, Patterns of Growth and Persistent Fragilities, URL: http://www.Bagimsizsosyalbilimciler.org

Isik, Sayim (2004): Application of the Post-Keynesian Financial Fragility Approach to the Financial Crises in Turkey (I99I-200I) (in Turkish), in: Iktisat, Isletme/Finans, Vol. I9, No. 218, pp. $5 \mathrm{I}-77$

Istanbul Chamber of Industry (2003): Turkey's Top 500 Industrial Enterprises, Istanbul: ICI Kregel, Jan A. (1998): Yes, It Did Happen Again - A Minsky Crisis Happened in Asia, Jerome Levy Economics Institute Working Papers, No. 234

Mencinger, Joze (2003): Does Foreign Direct Investment Always Enhance Economic Growth?, in: Kyklos, Vol. 56, No. 4, pp. 49I-508

Minsky, Hyman P. (1982): Can »It« Happen Again? A Reprise, in: Challenge, Vol. 25, No. 3, pp. 5-I3

Minsky, Hyman P. (1986): Stabilizing An Unstable Economy, New Haven, London: Yale University Press

Onaran, Özlem (2006a): Speculation-led Growth and Fragility in Turkey: Does EU Make a Difference or »Can It Happen Again«?, in: Hein, Eckhard/Heise, Arne/ Truger, Achim (eds.), Macroeconomics and Macroeconomic Policies - Alternatives Approaches to European Policies, Marburg: Metropolis, pp. 199-226 
Onaran, Özlem (2006b): Labor's Share in Developing Countries in the Era of Globalization, Annual conference of the Union for Radical Political Economy [URPE], Boston, held in January 2006

Onis, Ziya/Bakir, Caner (2005): Turkey's Political Economy in the Age of Financial Globalization: The Significance of the EU Anchor, Europeanization and Transformation: Turkey in the Post-Helsinki Era, Koc University, 2-3 December

Schroeder, Susan K. (2003): A Minskian Analysis of Financial Crisis in Developing Countries, University of Bremen, Bremen Contributions to Institutional and Social Economics, No. 50

State Institute of Statistics [SIS] (1950-200I): Survey of Employment, Payments, Production and Tendencies in Manufacturing Industry, electronic data, Ankara

State Planning Organisation [SPO] (2006): General Economic Targets and Investments, 2007, Ankara: SPO

Taylor, Lance (1998): Lax Public Sector, Destabilizing Private Sector: Origins of Capital Market Crises, New School, Center for Economic Policy Analysis Working Paper Series, No. 3

The Central Bank of Turkey (2006): Financial Stability Report, Ankara: CBT

The Economist (2006a): Shares in Emerging Economies: A Nasty Spillage, June Io, pp. 79-80

The Economist (2006b): Emerging Markets: Spot the Difference, July 8, p. 74

The Economist (2006c): Emerging Market Turbulence: A Turkish Bath? June 3, pp. 78-79

UNCTAD (2006): World Investment Report, Geneva: United Nations

Uygur, Ercan (200I): Turkey From Crisis to Crisis: 2000 November and 200I February Crises

(in Turkish), Turkey Economy Institute, Working Paper, No. 200I/I

Voyvoda, Ebru/Yeldan, Erinc (2005): Turkish Macroeconomics Under the IMF Program: Strangulation of the Twin-Targets, Lopsided Growth and Persistent Fragilities, URL: http://www.Bagimsizsosyalbilimciler.Org/Yazilar_Uye/Vydeco5.pdf

Yapi Kredi Bank Economic Research Department (2007): Monthly Bulletin, Istanbul, mimeo Yeldan, Erinc (2002): On the IMF-directed Disinflation Program in Turkey: A Program for Stabilization and Austerity or a Recipe for Impoverishment and Financial Chaos?, in: Balkan, Nesecan/Savran, Sungur (eds.), The Ravages of Neo-Liberalism: Economy, Society and Gender in Turkey, New York: Nova Science

Yeldan, Erinc (2007): Patterns of Adjustment Under the Age of Finance: The Case of Turkey As a Peripheral Agent of New-Imperialism, The Annual Meetings of URPE, Chicago, 5-7 January

Yenturk, Nurhan (1999): Short-Term Capital Inflows and Their Impact on Macroeconomic Order: Turkey in the I990s, in: Developing Economies, Vol. 37, No. I, pp. 89-II3 